\title{
製紙機械の安定した連続運転を実現する合成潤滑油*
}

\author{
エクソンモービル L \& PS ○ピーター ワイス，ステファン エリオット \\ エクソンモービルマーケティング(有) 高野＼cjkstart聡，笠井 隆志
}

\section{Synthetic Solution for Pulp and Paper Mills}

Peter J. Weis and Stephen W. Eliot

ExxonMobil L \& PS

Satoshi Takano and Takashi Kasai

ExxonMobil Marketing Services Pte. Ltd.

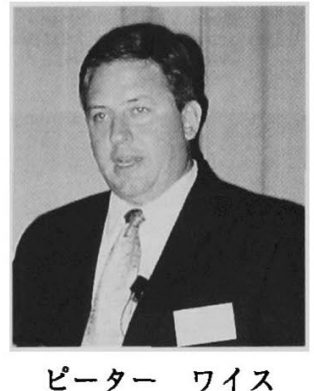

There are a lot of myths today around the use of synthetic lubricants. However, the realization that synthetic lubricants can contribute to a pulp \& paper mills bottom line is becoming a reality.

The objective of this presentation is to provide an understanding on the use of synthetic lubricants and to assist mill personnel in the evaluation of their application. To accomplish this the term "synthetic" needs to be defined. The different types of synthetic lubricants along with the specific performance benefits will be addressed. We would like to provide a technical answer on the benefits of using synthetic lubricants and how to identify the areas in the mills where the benefits may be achieved.

Specific mill case histories will be highlighted to support how the benefits are realized. These case histories will involve both synthetic oil and grease applications. Synthetic lubricants must be able to do what a mineral oil lubricant can not or provide an economic benefit. We would like to provide ideas for personnel to go back to their mills and be able to identify cost saving areas.

分類： $W_{0}$ その他, $Z_{2}$ 紙パルプ産業一般

\section{1. 緒言}

弊社は長年に渡り世界中の製紙メーカーに対し潤滑 油を供給してきた。モービルが 1999 年に供給した製 紙機械向け潤滑油の量は約 5 万キロリットルで, 全世 界の約 $25 \%$ (エクンンモーピル推定) のシェアを有 している。

安定した連程連転の実現に潤滑油は欠くことのでき ないものであるが, 近年の著しいマシン高速化, 製品 品質の向上に伴って高温下で運転されることも多く,
潤滑油への性能要求はさらに搌しいものとなっている。 また，環境への配虑から廃杗物量を削減するために潤 滑油の交換周期の延長を求める声も多く，この点にお いても潤滑油の高性能化が必要となっており，合成油 の適用が望ましい潤滑箇所が增加している。

合成油は目的とした構造の化合物を化学反応により 作り出した油であり, 求める性能に合わせて数多くの 種類が存在する。ここでは製紙機械について，近年の 製紙機峨用潤滑油への要求項目, 䌘社の潤滑油開発へ の取り組み，適正な潤滑油の使用による実機での経験 について過去数年の取り組みを紹介する。

*平成 12 年度年次大会講演（講演 No. B 16, 17） 


\section{2. 製紙機械が求める潤滑油への要求項目}

\section{1 製紙機械用潤滑油に求められる性能}

一般の循環系統油に求められる性能は適正な粘度, 長寿命 (酸化安定性), 耐摩耗性, 万過特性, 低泡立 ち性等が挙げられる。製秖機械の潤滑油についてはこ れに加えて防錆/防食性, 水分離性, スラッジ分散性 が加わる。特に防錆性については水, さらには白水が 混入した際にも十分な防錆性能を発揮できるようにし なければならないため，特に要求の蕨しい項目である。

近年紙の需要増に対応するため機械の新設や増設, さらに既存設備の改造が行われた結果, 現在稼動して いる設備はスピードアッブに伴う洞滑箇所の高温化な ど, 潤滑油への要求は紪しくなっている。さらに㻴境 への負荷軽減の钼点から油の使用量削減が叫ばれてお ク，使用条件が著しく䚺しくなっているにもかかわら ず, 潤滑油の長寿命化（熱・酸化安定性の向上）が求 められている。

以下に製紙機械用洞滑油に要求される性能をまとめ てみる。

·長寿命

・耐摩耗性

・低スラッジ性

・水分離性

・防錆/防食性

·万過性能

・低泡立ち性

・ベアリンクの疲労防止

・粘度温度特性（高粘度指数）

膶滑油の開発では要求項目の選定と, 各項目につい てどの程度の性能が必要となるかを決定する過程が, 開発初期の最重要課題でありこの過程に狂いが生じ ると，その後の方向性は全く異なる㑡に進む可能性が 高い。

次に決定した要求性能を満たすへく処方を決定して いくのであるが，一般に工業用洞滑油の処方は $95 \%$ 以上の基油と $5 \%$ 以下の添加剬の混合物である。潤 滑油の性能は基油に由来する部分と添加剤の効果によ る部分とがあり，基油に由来する性能は添加剤によっ て改良できないことが多いため, 基油の選定は重要で ある。また，ある特定の性能に注目しすぎる余り，他 に悪影響を及はすような処方をしないように，常に性 能のバランスに注意する必要がある。

\section{3. 合成油の特長と種類}

潤滑油に求められる究極の性能は摩摬, 犘耗が全く
無く，あらゆる条件下において物理的，化学的な変化 が無いことである。天然に存在する物質から作られる 鉱物油や天然油脂類ではこれらを実現することは不可 能であり，また改良の余地はそれほど残されていない が，構造を特定して製造することのできる合成油には 性能向上の余地は十分に残されていると思われる。

\section{1 合成油の種類}

天然に存在せず化学合成によって作った油を合成油 とするならば,この世には数限りない種類の合成油が 存在することになる。しかし潤滑油の用途として性能， 価格の面から使用される合成油の種類は限られる。そ の分類に関しては，種々の分け方が考えられるが，使 用量と構造により大別すれば炭化水素系 [ポリアルフ アオレフィン (PAO), ポリイソフチレン (PIB)，ア ルキル芳香族]，エステル系（ポリオールエステル， ジエステル), ポリグリコール系（水溶性, 油溶性), その他（フェニルエーテル，リン酸エステル，シリコ ン油等）とすることができる。これらの合成油の中か ら各潤滑条件に適した油を選定していくことが求めら れる。

\section{2 成油の優れた特性}

合成油はその種類によって様々な特徵を持っている。 代表的なものとしては以下のようなものが挙げられる。

\section{2 .1 粘度特性}

重合系（ある繰り返し単位を重合させた構造をもつ 化合物）の合成油は粘度の調節が可能で, 重合度によ り低粘度から高粘度まで自由に製造できる。中でも $\mathrm{PAO}$, エステル，ポリグリコールといった分子の届 曲性の良いものは温度によって見かけの分子の大きさ が変化するため温度に対する粘度変化が小さい（粘度 指数が大きい)。一方で分子構造中に立体障害となる 芳香核やかさ高い側鎖を持つものは粘度指数が小さい が，粘度圧力係数が大きく高トラクションを得られる。

\subsection{2 酸化安定性・熱安定性}

ポリオレフィン系の合成油は構造的には鉣油と類似 しているため, 基油単体としての熱・酸化安定性は鉱 油のそれと殆ど変わらない。しかし，ポリオレフィン には鉱油に含まれているような不純物が含まれていな いため添加剤の添加効果が高く，適切な添加剤処方に より優れた安定性を発揮する。また，分子量分布が非 常に狭いので蒸発損失は少ない。

エステル系の合成油は構造的に熱・酸化安定性が優 れており，特に $\beta$ 位の炭素に水素が結合していないた ンダードエステルは他のエステルに比べても優れた安 定性を発揮する。また，蒸発椇失は非常に少なく，引 火点も高い。 
ポリグリコール系の合成油は基油のみで考えると他 の基油に対して熱・酸化安定性に劣る。劣化の際には, 構造中のエーテル結合部の反応性が高く, 反応の結果 低分子のアルデヒド，カルボン酸の形で空気中に飛散 する。その結果スラッジの生成は少ない。

\section{2 .3 低温流動性}

合成油は釷油と異なりワックス分を含まない。ワッ クス分は低温度領域で油中から析出し, 3 次元的に結 晶が成長して流動性が妨げるられるため，一般的な鉱 油でー 5 C から-10ㄷ にて流動性が失われる。それ に対し合成油はワックス分を含まないため，例えば PAOであればー $50^{\circ} \mathrm{C}$ 以下でも流動性がある。エステ ルやポリグリコールは分子構造に極性を持つため PAO より若干劣るものの，優れた低温流動性を示す。

\section{3 合成油採用によるメリット}

前述した合成油の特長を生かし，合成油を採用する ことによって以下のメリットが期待できる。

\subsection{1 エネルギー効率の向上}

合成油は粘度指数が高いため潤骬部分の温度が高い 場合，鈗油よりも1つ下の粘度グレードの油を使用で きる場合がある。油の粘性（内部）抵抗を低隇するこ とができる。また低温流動性に優れるため機械の起動 時などには大幅なトルク低減が期待できる。従って， 内燃機関や各種歯車用の潤滑油として合成油が使用さ れた場合には，鉱油に比べてエネルギー効率が向上す る。特にウォームギヤについては，油の撜找抵抗がエ ネルギー損失に与える影響が大きいため, 合成油の採 用によるメリットが大きい。図 1 は弊社が過去に塞施 したウォームギヤでの効率に関する調查の結果である。 この評価では合成油の使用により鉣物油使用時に比べ $2 \%$ から $8.8 \%$ の效率向上が確認されている。

\section{3 .2 使用温度範囲の拡大}

以下のような理由から高温側, 低温側ともに使用温

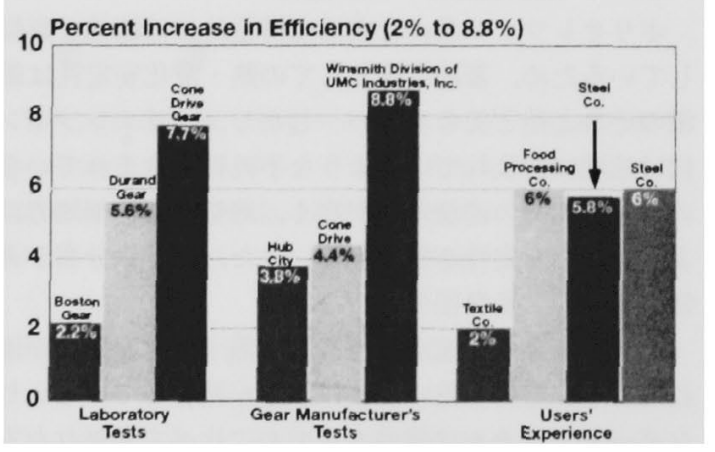

図 1 合成油の使用による効率の向上（鉱物油使用時 との比較)
度範囲を拡大できる。

高温側：

・粘度指数が高いので高温でも粘度を保てる。

·熱・酸化安定性に優れている。

・分子量のばらつきが少なく蒸発量が少ない。

低温側：

・粘度指数が高いので低温領域で粘度の上昇が少な い。

・ワックス分を含まないため流動点が低く，低温流 動性に優れる。

\subsection{3 適用範囲の拡大}

潤滑油が使用される各種機械装置は, 日々改良が加 えられ, 高出力, 高効率, 小型といった方向性で進歩 を重ねている。これらはその殆どが潤滑油にとって過 酷な方向であり，従来の鉱物油では対応できない場合 があった。そのような場合には合成油を適用すること で，それを解決できる場合も多い。

3.3.4 メンテナンス/オペレーションコストの低滅 合成油の適用により大幅なメンテナンスやオペレー ションコストを削減できる。合成油は一般に鉱物油に 比較して長寿命で適用温度範囲も広く，低蒸発性であ るため, 油の交換周期の延長，季節每に粘度の異なる 油への交換が不要、油補給量の低減が可能である。

\section{4. 製紙機械用潤滑油の開発}

4.1 モービルの潤滑油研究開発

弊社の潤滑油開発は製紙機械メーカー殿, ベアリン ク等の機械要素メーカー殿及び製紙会社殿との連携に より成り立っている。各メーカーと機械や油の技術動 向についてディスカッションを綝り返し, 油の要求性 能に対する方向性をお互いに確認し合いながら，その 要求性能に基づきラボ試験, 弊社独自のテストリグを 使用した評価，実機試験，特定地域での多数の実機評 価を行っていく。特に弊社における長年の開発におい て培われたテストリグでの経験は，試作油の実機での 性能を予測するのに非常に役立っている。

\section{2 製紙機械用潤滑油の開発課題}

製紙機械用潤滑油には製紙機械ならではの以下のよ うな要素が絡んでくる。

・高温での操業

・各種材料の混入（硫酸バンド, マグネシウムケイ 酸塩, 白土等)

・腐食性のロール洗浄材の混入

- 多量の水の混入 (プロセス水, 冷却水, 凝縮水)

・メンテナンス頻度の減少

・油補給量の減少 
これらの要素を考虑に入れて先に挙げた製紙機械用 潤滑油の要求性能を満たすように, 開発を進める必要 がある。

\section{5. 潤滑油性能の評価}

なぜ JIS，ASTM 等の標準化された試験のみではな く独自の試験を行うのかと疑問に思う方も多いことと 思う。確加独自の試験方法を用いることは，競合他 社品との性能差を第三者が判断することを難解にして いる。しかしながら，その評価を導入することによっ て実機に近い状態での潤滑油性能を見ることになるた め，各種潤滑油の性能差をより明らかにすることがで きるのである。従って優れた評価方法を持つ事は, 潤 滑油の開発には欠かせないものであり，試験法自体の 開発も必要不可欠である。

弊社では機械メーカー殿の試験方法と弊社独自の試 験方法にて評価を行っている。以下に代表的な幾つか の試験方法と評価について述べる事とする。

5.1 FAG FE-8 ベアリングテストリグ（写真 1)

この武験機は評価する油やグリースの種類に合わせ て様々な評価を行うことができる。製紙機械用潤滑油 の評価では油の洞滑性, 酎摩耗性, 清净性, 劣化度合 い，添加凨の消耗度を評価することができる。特にこ の試験では油の性状によりヒーターボックス内のスラ ッジ生成に差が出る。熱・酸化安定性, 清浄性に劣る 油の場合ヒーターポックス内のブレートに多量の堆積 物が生成する（写真 2)。

5.2 ペーパーミルベアリングリグテスト（写真 3)

高温下での清浄分散作用と酸化安定性を評価する試 験。球面軌道ころ軸受に高温の油を循環式で供給する。 また，定期的な水分の混入も行う。この状態で数百時 間運転した後の堆積物量及び油の劣化状態を判定する。

\section{3 テーパーローラーベアリングテスト}

水分の混入した油を使用した場合のペアリング寿命 を測定する試験で，油の疲労防止性能を評価する。

5.4 加速劣化試験（プロパティーリテンションテ スト)

油の劣化と清浄分散性を評価する試験。高温, 長時 間の循環試験で，定期的に水を混入させながら実施さ れる。油の劣化度合いと系統内のフィルターの清浄度 合いによって，循環系等油に必要とされる酸化安定性， 万過性, 清浄分散性を評価し, 潤滑油性能が長時間の 使用によってどのように変化していくのかを検訨する。

\section{5 薄膜防銷試験}

この試験はオイルタンクの気相部分での防錆性に視 点をおいた試験である。鉄板を油に浸し，高温のエア

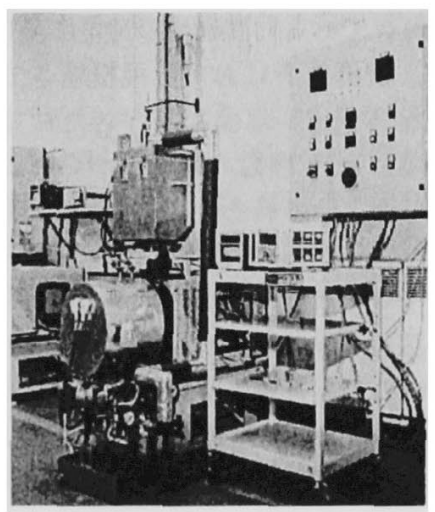

写真 1 FAG EF-8 テストリク
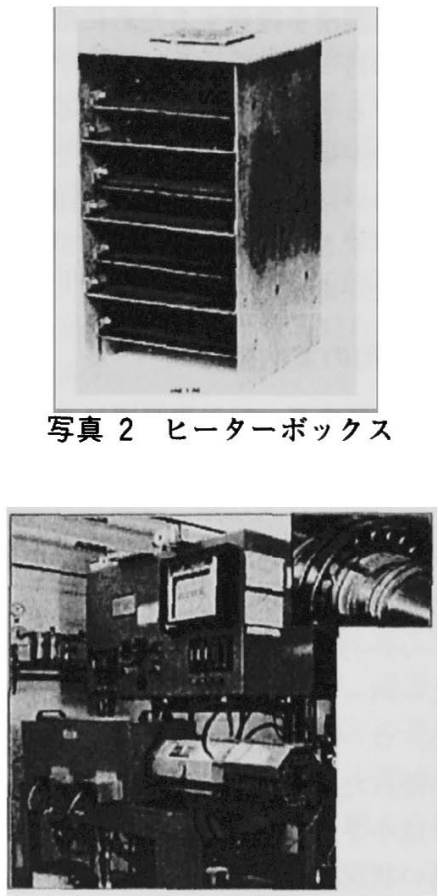

写真 3 ペーパーミルベアリンクテスト

オープン中に吊るしておく。これにより鉄板の表面に は極めて薄い油の膜のみが残った状態になり，これを 湯煎の上に設置して板に錆が出るまでの時間で評価す る。

\subsection{B-10 酸化試験}

4 種類の触媒金属を入れた潤滑油を高温の条件下で 空気の吹き込みを行い油の劣化を測定する試験。試験 時間と試験温度により幾つかの試験条件がある。

\section{6. 適正潤滑油の選定}

機械の連続した安定操業のためには，適正な潤滑油 
の選定が不可久である。潤滑油の選定に際して最も重 要な項目は, 潤滑筒所における油膜厚さであり通常 EHL（弾性流体潤滑）理論に基づいた計算式によっ て算出される。EHL 理論の詳細については紙面の関 係上割愛するが，その概念を転がり軸受の潤滑理論を 例にして簡単に述べる（図2）。

転がり軸受での潤骬は点ないし線の接触により形成 される外接表面 (ノンコンフォーミングサーフェス) において行われる。荷重下で転がり軸受は高圧接触の ため, 金属の弾性変形を生じ, この変形により出来た 微小表面の中に取り込まれた油が, 高圧下の潤滑油膜 を形成する。この油膜を EHL 油膜 (弾性流体油膜) と呼ぶ。EHL 油膜は極めて薄く $0.25 \mu \mathrm{m}$ のオーダー にあり，適正な潤滑を確保するためには，相接する二 面の表面粗さの持つ突起を充分に分離するに足る厚さ の油膜を形成する必要がある。薄すぎる油膜では, こ れらの突起部分が接触を起こし, 摩擦を增大し, 摩耗 やカジリ，あるいは疲労による軸受の損傷を招く結果 となり，逆に厚すぎる油膜では転動体が回転せずに滑 りを起こすことがある。

\section{7. 合成油適用の実例紹介}

これまで, 合成油の優れた特性を述べてきたが、こ こでは合成油の実際の適用例をぺーパーミルの部分を 例にとって紹介する。ペーパーミルでは潤滑油が非常 に高温にさらされることが多く, 合成油の適用による メリットの大きい個所である。

\section{1 スーパーカレンダー}

近年のスーパーカレンターは紙の表面を滑らかに仕 上げるため, ロールの表面温度は高く, 潤滑油に対し て高温での優れた酸化安定性が求められる。しかも才 イルタンクは小さくなる傾向にあるため, 熱負荷が常 にかかり易い状況となっている。合成油の適用により， この蕨しい条件下においても安定した長期にわたる連

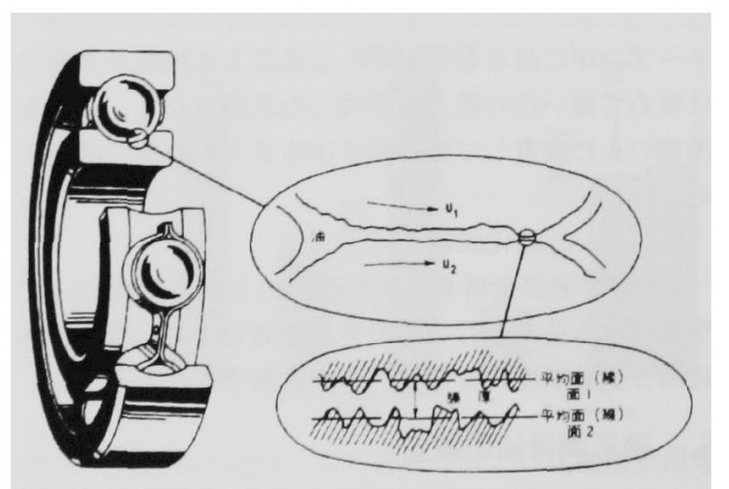

図 2 玉軸受における玉と内輪との接触面の概要図

\section{続運転が実現できる。}

\section{2 攪拌機のギヤボックス}

油温が上昇してしまうギヤボックスの潤滑油には， 合成油を使用することで温度低減の効果（潤滑油内部 粘性抵抗の減少), 上り厚い潤滑膜の形成（歯車謎み 合い筒所及び軸受部）効果が期待でき，ギヤボックス の安定した長期にわたる連続運転が可能となる。

\section{3 ドライヤーパートのベアリング}

弊社は各軸受に形成される閏滑油膜厚さを EHL 理 論に基づいて計算することが可能であり，適正な油膜 厚さの製品を選定することで，大幅にベアリング寿命 を伸ばすことができる。潤滑籄所が高温になる場合に は合成潤滑油の適用により潤滑油の粘度を大きく変更 することなく適正な油膜厚さを維持できる。もちろん， 潤滑油自体の寿命も長く，かつシステムを長期にわた りきれいに保つことができる。

これらの閏滑箇所においても，それほど戦しくない 運転条件下では，鉱物油でも十分に優れた性能を発揮 することができる。高温箇所の潤滑など鉱物油の適用 が難しい箇所の潤滑や, 省エネルギー効果, 機械寿命 の延長が要求される場合には, 合成油の適用が望まし い。合成油は油の単価は高いものの, 機械寿命の延長, メンテナンスコストの低減, 省エネルギー効果などか らトータルとしてのコストセービングを可能にする。

ここで再度合成油の優れた特長をまとめる。

・粘度温度特性（高い粘度指数）

·熱・酸化安定性

・低温流動性

・油寿命の延長/油交換の減少

・エネルギーロスの低隇

\section{・低蒸発性による消費量の低隇}

最後に合成油によるトータルコストセービングを端 的に表した，あるエッセイストのことばを紹介して終 わりとしたい。

"It's unwise to pay too much, but it's worse to pay too little. When your pay too much, you lose a little money. that is all. When you pay too little, you sometimes lose everything. because the thing you bought was incapable of doing the thing it was bought to do.

The common law of business balance prohibits paying a little and getting a lot-it can't be done.

If you deal with the lowest bidder, it is well to add something for the risk you run, and if you do that, you will have enough money for something better" (John Ruskin, English Essayist, 1819-1900) 


\title{
海外における高温ジャケットロールによる製紙カレンダーの運転実例
}

\author{
一ソフトカレンダー，及びハードニップカレンダー一
}

\section{トクデン株式会社 シンガポールオフィス 藤本 壹裕}

今日, 日本をはじめ, 海外の多くの製紙場で, ペーパ, 及び板紙のカレンタに, 高温ジャケット ロールが, 数多く運転されている。主として，ソフトカレンタとハードニップカレンタが, 高温で, し かも高速で運転されている。

最近，とみにあらゆるペーパーや板紙が，蓠があって平滑性がよいこと，そして印刷性に優れている ことが要求されてきている。また，ハイグロスであることも要求されている。これらペーパー，及び板 泜の品質向上の要求には，高温ジャケットロールが要求を满たしている。すなわち, ソフトカレンタゃ ハードニップカレンタに組み込まれたジャケットロールが, 高温で, ワンバス及び低ニッブでカレンタ 辢けをれるので,これらの要求に応えている。

また, 従来, コーテッドペーパー (Coated paper) は, 高温ロールでのカレンタでは, カレンダ後の 表面仕上がり状悲に問題があった。水ふくれのような現象を起こしたり，コーティンクカラー (Coating Colour）が剥鹿するというようなことがあった。しかし，現在ではかなり，コーティンクカラーの開発 をされている。ソフトカレンターで, かなりの高温のジャケットロールによって運転をされている。そ の耛果は，碩客の满足を得るものとなっている。

また，板紙では，ハードニッブカレンター，すなわち，高温ロールで，ワンパスの低ニッブでのカレ ンダー掛けが重要である。徉来のよjに,6段や 4 段のマシンカレンダーでは,とても板紙の蓠を得る ことができない。

(本文 87 ベージ)

\section{製紙機械の安定した連続運転を実現する合成潤滑油}

$$
\begin{array}{rll}
\text { エクソンモービルL \& PS } & \text { ピーター ワイス, ステファン エリオット } \\
\text { エクソンモービルマーケティンク(有) } & \text { 高野 聡, 笠井 隆志 }
\end{array}
$$

今日，合成洞滑油の優れた面に閉する漠然とした理解があり，その一方で，合成潤滑油を製紙機械に 使用した場合，経費節娍をもたらすという現実がある。

本報の目的は，合成洞滑油の使用に関する理解を深め，合成洞滑油の製紙機械への適用の手だてとし ていたたくことである。まず合成」という言葉を説明し，異なった特長を持つ，さまざまな合成洞滑 油の種類について紹介する。合成洞滑油の特長は，下記の通りである。

(1)優れた粘度渴度特性，(2)高い热・酸化安定性，(3)優れた流動特性，(4)鉣物油との親和性（特にポリ アルファオレフィン)，(5オイル交換周期の延長，(6)摩擦損失の低減，(7)オイル消費量の低減

また，合成洞滑油がもたらす利益についての技術的なアドハイイスと，その製紙機械の適用箇所を見つ ける方法について逨べる。

合成潤滑油が鉱物油と比较して，いかに释費節娍に貢献するかについて，具体的な適用例を取り上げ

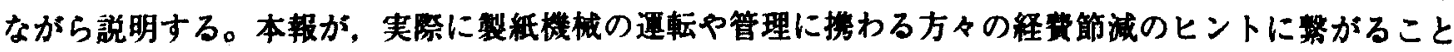
を望む。

(本文 96 ページ) 